NETWORKS AND GROUPS IN SOUTHEAST ASIA:

SOME OBSERVATIONS ON THE GROUP THEORY OF POLITICS

BY

CARL H. LANDÉ

Unizersity of Kansas Vol. LXVII, No. 1, March, 1973 


\title{
Networks and Groups in Southeast Asia: \\ Some Observations on the Group Theory of Politics
}

\author{
CARL H. LANDÉ \\ University of Kansas
}

Fifteen years ago the Committee on Comparative Politics, in the course of its grand design for the cross-national study of politics along the lines outlined in Gabriel Almond's classic introductory essay in The Politics of the Developing Areas, commissioned a series of investigations of "Interest Groups and the Political Process." I was one of the Committee's grantees.

One of our main tasks was to perform censuses of interest groups and to describe their work. On the whole the results were disappointing. The conclusion of most of those who examined developing polities was that "interest groups" do not play as important a part in the political process as had been expected. This conclusion is reflected in the fact that the Princeton series of Studies in Political Development, the major compilation of the product of the Committee and its grantees, includes as yet no volume on "Interest Groups and Political Development." And it seems unlikely that such a volume will appear in the near future.

But if Almond's list of conversion functions remains sound, and I think it does, then "interest articulation" must take place in any political system in which political decision making is a specialized task, and there must be structures to perform it. Almond and Powell, in their 1966 work, ammended the theory to take account of the disappointing performance of the four types of groups listed in Almond's 1960 essay, i.e., institutional, non-associational, anomic, and associational interest groups, by drawing attention to the importance of individuals as "articulators of their own interests." 1 But they added that individual self-representation is "commonly cast in the guise of the articulation of more general societal or group interests." This missed a crucial point: That in many develop-

\footnotetext{
${ }^{1}$ Gabriel A. Almond and G. Bingham Powell, Jr., Comparative Politics: A Developmental Approach (Boston: Little, Brown \& Co., 1966), p. 75. For Almond's earlier formulation, see The Politics of the Developing Areas, ed. Gabriel A. Almond and James S. Coleman (Princeton: Princeton University Press, 1960), pp. 3-64. For the paper which guided the research of the Committee's grantees, see Gabriel A. Almond, "A Comparative Study of Interest Groups and the Political Process," American Political Science Review, 52 (March, 1958), 270-82.
}

ing polities the great bulk of individual self-representation is self-representation pure and simple, without any pretense of a concern for the categorical interests of any collectivity, be it society as a whole or a subgroup within it. The purpose of this paper is to explore the structural basis and the consequences of pure and impure self-representation in several Southeast Asian political systems, and to suggest some propositions and models which, it is hoped, will explain some of their peculiar features.

At the outset, it may be useful to review the essentials of the "group theory" of politics, as well as some criticism of that theory. Stated in its broadest terms, the theory assumes that individuals act in politics largely as members of groups. A group is a set of individuals who share an attitude. They act together because they perceive that by doing so they are most likely to attain objectives consistent with the attitude which they share, and thus to gain similar individual rewards. Groups often, though not invariably, consist of persons whose_common attitude stems from the fact that they have some similar "background" characteristic such as sex, age, religion, occupation or social class. For this reason, much theorizing and research by political scientists in modern Western countries has focused on the assumed interrelationship among the socioeconomic background attributes of political actors, their political attitudes, and their political behavior.

The American version of the group theory comes to us from Arthur Bentley by way of David Truman and Earl Latham." Marxist theory makes a similar assumption, that men who have something in common, in this case social class, will and should act in unison in their collective interest. The now largely forgotten theorists of the fascist corporate state also maintained that individuals who are alike do and should act in unison, though in their view the various "corporations" composed in each case of a functionally specialized sector of the economy should not clash but, like the organs of a

2 Arthur F. Bentley, The Process of Government (Chicago: University of Chicago Press, 1908); David B. Truman, The Governmental Process (New York: Knopf, 1951); Earl Latham, The Group Basis of Politics (Ithaca: Cornell University Press, 1952). 
living organism, work in harmony for the higher purposes of the corporate state. ${ }^{3}$

In all versions of the theory, individuals who become aware of their similar attitudes and/or background are assumed to find it to their advantage to create formal organizations of some sort, the better to advance their shared goals or interests, or to perform their organic functions. But formal organization is not essential to the theory in its broadest form. The essential feature is that individuals who are alike in some respect are more likely to act together than individuals who are not.

As a prescription for self-interested action, the group theory has grave shortcomings. Mancur Olson, an economist, has pointed out that if the purpose of group action is merely to achieve categorical goals through which all members of a category will derive benefits, an individual member has no great incentive to contribute to the common effort. For even if he does not, he can expect to share in the fruits of that effort simply by being a member of that category. ${ }^{4}$ The theory has another serious weakness: It assumes that governmental action must take a categorical form: that government, or at least modern government, proceeds according to the rule of law, that is, that laws will be enforced rigidly and impersonally whatever their content, and that individuals can benefit only through the operation of laws which provide similar benefits for all others similar to themselves. Only if this is assumed-and in many developing countries it is a highly dubious assumption-need individuals resort to the cumbersome method of advancing their private interests by working for the similar interests of countless others. These criticisms of the group theory lead to some alternative conceptualizations of political structure, including interest articulation structure: those of the dyad and the dyadically structured system. ${ }^{5}$

${ }^{3}$ See Giovanni Gentile, "The Philosophical Basis of Fascism," and Alfredo Rocco, "The Political Doctrine of Fascism," in Readings on Fascism and National Socialism, Department of Philosophy, University of Chicago (Denver: Allan Swallow, n.d.). For a discussion of the corporate state in practice, see Michael $\mathrm{T}$. Florinsky, Fascism and National Socialism: A Study of Economic and Social Policies of the Totalitarian State (New York: Macmillan, 1938), pp. 86-100.

${ }^{4}$ Mancur Olson, Jr., The Logic of Collective Action (Cambridge: Harvard University Press, 1965).

${ }^{5} \mathrm{~A}$ more rudimentary version of the dyadic model, developed here, may be found in Carl H. Landé, Leaders, Factions, and Parties: The Structure of Philippine Politics, Yale Southeast Asia Studies Monograph Series, No. 6 (New Haven: Yale University Southeast Asia Studies, 1965), Appendix II, "Group Politics and Dyadic Politics: Notes for a Theory." An earlier state-

\section{The Nature of Dyads}

A standard anthropological dictionary defines a "dyadic group" as "a pair of human beings in a social relationship." This simple definition fits almost any two-person group. For the purposes of this discussion, however, some distinctions between different types of dyads are needed.

First, it is useful to distinguish between corporate dyads and exchange dyads. The former consist of two persons who, in matters that interest the analyst, behave as one. The latter consist of two persons who maintain their separate identities, but are engaged in relationships of exchange. Typically in exchange dyads the two members give or lend property to each other. But its ownership at any point in time, is individual, not joint.

Exchange dyads in turn can be subdivided into supportive and antagonistic ones. In the former, the two members trade things of value. In the latter they trade injuries.

In actual dyadic relationships, of course, these analytically distinct forms can be mixed. The relationship between the United States and the Soviet Union, for example, now involves both supportive and antagonistic exchanges. And a marriage involves both the pooling and the exchange of resources.

For political scientists, exchange dyads, especially supportive ones, are of primary interest. In the remainder of this paper, when I use the term "dyad" I shall mean supportive exchange dyads unless another type is specified. Some characteristics of dyads, other than those mentioned above, follow:

Dyads may bind together persons who are alike or unalike. The ease with which dyads cut across occupational and class lines makes them of particular importance to political scientists

ment is found in "Politics in the Philippines," Diss Harvard University, 1958. The relationship between dyadic political structure and cognatic kinship is discussed at greater length in a paper, "Kinship and Politics in Pre-Modern and Non-Western Societies," which was submitted to the American Political Science Review in 1961. While not published at the time, it now appears in Southeast Asia: The Politics of National Integration, ed. John T. McAlister, Jr. (New York: Random House, 1973), pp. 219-233. These writings owe a heavy debt to the late Robert N. Pehrson, whose classic study, The Bilateral Network of Social Relationships in Könkämä Lapp District, Indiana University Publications, Slavic and East European Series, Vol. 5 (Bloomington: Indiana University Research Center in Anthropology, Folklore, and Linguistics, 1957) introduced me to the peculiarities of dyadic structure.

- Charles Winick. Dictionary of Anthropology (New York: Philosophical Library, 1956), p. 242. 
interested in the processes of national integration and conflict resolution.

Benefits obtained through dyadic exchanges tend to be particular rather than categorical. Each partner must reward the other, but need not support the goals of the whole category to which the other belongs.

Dyadic exchanges tend to involve some degree of reciprocity, but need not achieve exact reciprocity. Reciprocity is most likely to be approximated when the relationship is voluntary for both partners, when both must compete freely with other suppliers of the same rewards, when both control resources of roughly equal value, and when the relationship involves a minimum of antagonism. The achievement of exact reciprocity at any point in time, however, facilitates the termination of the dyad, and thus may be avoided.

Dyads usually are linked to other dyads in larger structures, or are capable of being so linked. All the dyadic ties within a society or subsociety constitute its dyadic network.

Each member of a dyadically structured system has a personal combination of dyadic partners which is uniquely his own. The personal alliance systems of different individuals may overlap and intersect, but are rarely identical. An individual's personal set of dyadic relationships constitute his dyadic $w e b$. As in a spider web, the structurally most important strands are those which extend outward from the central individual by whom or in whose behalf various of his allies, plus some of their allies, are brought into action. As in a spider web, the concentric circles of connecting links are of less importance. They represent the cooperation among the central individual's allies that takes place in their common effort to assist him. Insofar as a system is structured dyadically, i.e., as a network, organized action involving many persons tends to begin with the effort of one individual to mobilize members of his web, and then of their webs, in support of what he regards as desirable goals.

Personal webs, like individual dyads, can be subdivided analytically into vertically and horizontally structured ones. Vertical webs are those whose central individual has greater status, resources or power than his various dyadic partners have. As a general designation for most vertical webs of a political nature, I suggest the term "personal following." A specific subtype of this general type are patron-client systems. The distinguishing feature of archetypal patron-client relationships is a broad but imprecise spectrum of mutual obligations con- sistent with the belief that the patron should display an almost parental concern for and responsiveness to the needs of his client, and that the latter should display almost filial loyalty to his patron-beliefs reflected by the tendency for familial appellations to be employed in the relationship. The operation of patron-client systems in politics has been the subject of three recent articles in the American Political Science Review. They are characteristic of traditional societies, and appear to be on the decline. Other types of personal followings, however, are likely to be with us for some time to come.

Horizontal webs are those whose central individual has status, resources or power roughly equal to those of his various partners. For these, when they are political, the term "personal alliance system" seems appropriate. An example is an individual congressman's log-rolling arrangements with various of his fellows. All the log-rolling arrangements in Congress constitute a network.

The various dyadic ties within an individual's web may differ in the quality and quantity of their exchanges. Where this is the case, graded favoritism in the treatment of different partners usually is made explicit.

The dyadic webs of individuals may differ in size. The number of one's alliances tends to be limited by one's material resources, and to be positively related to one's status and power.

Dyadic structures tend to be most important, or most noticeable, where discrete structures are in short supply. That is to say, in systems which are small and premodern. Anthropologists therefore have been interested in them for some time. But political scientists, whose models are mainly of modern Western derivation, until recently have given them little attention. ${ }^{7}$

${ }^{7}$ There is a growing body of literature dealing with dyadic structures and in particular with patron-client relationships. Some seminal studies which are not mentioned elsewhere in this paper include the following: For Southeast Asia: James C. Scott, "Patron-Client Politics and Political Change in Southeast Asia," American Political Science Review, 66 (March, 1972), 81-113. For South Asia see Frederik Barth, Political Leadership among Swat Pathans, London School of Economics Monographs on Social Anthropology No. 19 (London: The Athlone Press, 1965), pp. 71-126. For Northern Europe see Otto Blehr, "Action Groups in a Society with Bilateral Kinship: A Case Study of the Faroc Islands," Ethnology, 3 (July, 1963), 269-275. For the Mediterranean area see Jeremy Boissevain, "Factions, Parties and Politics in a Maltese Village," American Anthropologist, 66 (December, 1964), 1275-1287; and by the same author, "Patronage in Sicily," Man, New Series 1 (March, 1966), 18-33. For Latin America see George M. Foster, "The Dyadic Contract: A Model for the Social Structure of a Mexican Peasant Village," American Anthropologist 63 (December, 1961), 1142- 
With a view to exploring various forms which dyadic structure can take and various tasks which they can perform, I shall describe certain elements of four Southeast Asian political systems, each at a different point along a rough scale of modernization, and each imbedded in a different religious tradition. These systems are: the pagan Kalinga of Northern Luzon in the Philippines; the Tausug, a Muslim society in the Southern Philippines; the Thera- vada Buddhist monarchy of Thailand during the Ayudhya and Bangkok periods; and the predominantly Catholic Republic of the Philippines.

\section{The Kalinga}

The first and most "primitive" example of a Southeast Asian polity is that of the Kalinga, one among several pagan peoples who inhabit the mountain region of Northern Luzon. During the period of American colonial rule, the Kalinga, or at least those of them who live near the several roads which have been built through the mountains by the colonial administration, have come increasingly under the influence of the outside world. But many of their traditional institutions survive, or survived long enough to be observed by anthropologists.

The following description of Kalinga political structure is based on studies by Roy Franklin Barton and Edward P. Dozier. ${ }^{8}$ From them one learns that like many primitive societies, Kalinga society until recently was organized almost wholly on the basis of kinship ties. Ka-

1173; and by the same author "The Dyadic Contract in Tzintzuntzan, II: Patron-Client Relationship," American Anthropologist 65 (December, 1963), 1280-1294 For Africa see C. W. Gutkind, "Network Analysis and Urbanism in Africa: The Use of Micro and Macro Analysis," Canadian Review of Sociology and Anthropology, 2 (May, 1965), 123-131. For theoretical works which are not limited to specific countries or regions see John W. Thibaut and Harold H. Kelley, The Social Psychology of Groups (New York: Wiley, 1959), especially Part I, "Dyadic Relationships," pp. 9-187; John A. Barnes, "Networks and Political Process," in Social Networks in Urban Situations, ed. J. Clyde Mitchell (Manchester: Manchester University Press, 1969); John Duncan Powell, "Peasant Society and Clientist Politics," American Political Science Review, 64 (June, 1970), 411-425; René Lemarchand, and Keith Legg, "Political Clientelism and Development," Comparative Politics, 4 (January, 1972), 149-178; and Norman E. Whitten, Jr. and Alvin W. Wolfe, "Network Analysis," prepared for Chap. 3, The Handbook of Social and Cultural Anthropology, ed. John J. Honigmann (Chicago: Rand-McNally, in press) which includes an extensive bibliography.

${ }^{8}$ Roy Franklin Barton, The Kalingas: Their Institutions and Custom Law (Chicago: University of Chicago Press, 1949); and Edward P. Dozier, Mountain Arbiters: The Changing Life of a Philippine Hill Peo. ple (Tucson: University of Arizona Press, 1966). linga kinship structure, like that of the other Southeast Asian societies described here, as well as of those of Northern Europe, is a type which anthropologists call "cognatic" or "bilateral."

The interesting characteristic of cognatic kinship, from the point of view of this paper, is that outside the bounds of the immediate or "conjugal" family, its structure is essentially dyadic. In cognatic systems each individual, when he looks beyond his conjugal family, finds himself surrounded by a circle of relatives, a collection of individuals whom anthropologists call the "personal kindred." It is made up of the descendants of all his ancestors of a certain earlier generation without regard to sex or the side of his family tree. In Kalinga, the personal kindred consists for each individual, of all descendants of his eight pairs of great-grandparents.

The main features of cognatic kindreds in Kalinga and elsewhere are as follows:

Kindreds are individual-centered. That is to say, each individual's kindred is defined with reference to himself, and exists primarily to serve his needs. After his death, it disappears as a distinctive entity.

Kindreds lack discrete external boundaries. Like the ripples from a stone dropped into a pool, the strength of kinship ties gradually declines as the genealogical and affective distance of kinsmen from ego increases.

The size and precise membership of each kindred depends largely upon the person at its core. It does so because he alone can decide how wide a circle of kinsmen he will attempt to cultivate, and which specific kinsmen he wishes to include among the functioning (as distinguished from purely nominal) members of his kindred. It does not depend exclusively upon his wishes, however, for each of those kinsmen with whom he wishes to maintain active ties must in turn be willing to maintain ties with him, i.e., must wish to count him as a member of his own personal kindred.

No two individuals other than siblings have identical kindreds. The kindreds of close relatives other than siblings overlap, but do not coincide. Further, as the kinsmen with whom an individual maintains effective ties depend in large part upon his choice, the effective kindreds of even siblings are not necessarily identical.

Thus a person's kindred is an outwardly radiating collection of dyads with one individual at its core. A community so structured-and this is the case with Kalinga communitiesmay be conceived of as a dyadic network of 
what George Peter Murdock describes as "interlacing and overlapping" kinship ties. ${ }^{9}$

Kalinga political culture is of a sort appropriate to an essentially anarchic society characterized by endemic feuding. Fighting skill and bellicosity are highly valued among men, being essential to survival. Contentiousness in litigation, a major preoccupation of the Kalinga, provides less dangerous opportunities for the display of truculence. Egocentrism and family centrism are characteristic of the society, being modified only by the personal loyalty to more distant kinsmen that is necessary for personal survival in a dangerous environment. Similar cultural traits will be noted in connection with some of the other Southeast Asian societies. Because there were in the Kalinga region until American times no "public" functionaries charged with the punishment of murderers or other offenders, the most important function of the kindred was, and to a large degree still is, to support the individual in conflicts over property or personal affronts which might lead to killing, or in case of actual killing to take vengeance through counter-killing against the killer or one of his kinsmen. ${ }^{10}$

While rallying to his support or avenging his death, the personal kindred of an individual, is in a sense, a "group." But it is an ephemeral group, and the willingness of an individual kinsman to participate depends largely upon the way he has been treated in the past by the individual at the kindred's core. In short it depends upon dyadic reciprocity.

It may be asked whether traditional Kalinga society contains any discrete groups of a corporate type. There are a few. One such group, found among the Kalinga as among other peoples, is the conjugal family consisting of a set of parents and their unmarried children. But the family is a temporary group, which disappears with the death of the parents and is replaced by the separate newly formed conjugal families of the children. Furthermore, the Kalinga family begins as a rather uncertain alliance, subject to fission under the stress of rival claims for loyalty from the parental families of each marital partner. Only with the birth of the

- George Peter Murdock, Social Structure (New York: Macmillan, 1949), p. 60. For an excellent discussion of the nature of groups resulting from cognatic descent, see Robin Fox, Chap. 6, "Cognatic Descent and Ego-centered Groups," Kinship and Marriage (Baltimore: Penguin Books, 1967), pp. 146-174.

${ }^{10}$ The personal kindred performed very similar tasks in early Europe. For an exploration of this subject see Bertha Surtees Phillpotts, Kindred and Clan in the Middle Ages and After: A Study in the Sociology of the Teutonic Races (Cambridge: Cambridge University Press, 1913). first child-i.e., with the appearance of an individual related by blood to both parental kindreds, does the marriage become a really stable one.

Among some neighboring and otherwise similar tribes, the people of Sagada and the Ifugao, there are to be found in addition to conjugal families and personal kindreds some cognatic descent groups. These consist of all the descendants, through both males and female links, of some prominent founding ancestor. ${ }^{11}$ Such groups, sometimes called "conical clans," are discrete. Their usefulness for the organization of society is limited, however, by the fact that, unlike unilineal descent groups, they overlap so that an individual, through different ancestral lines, may be a member of many such groups. In Sagada, conical clans since the introduction of electoral politics in American times, form the bases of political factions. In addition there are in Sagada clearly demarcated "wards" within which councils of old men settle disputes and organize rituals. But neither of these types of discrete structure are present to a significant degree in Kalinga. They are mentioned here because they remind one of the advantages which lie in discrete groups, and show how discrete groups can be created in simple cognatic societies.

The nature of the terrain inhabited by the Kalinga divides them geographically into a number of distinct settlements. These however had little that could be called local government prior to that which is now imposed by the lowland state. Nowhere in Kalinga, even in very small settlements where all regarded each other as kinsmen, was there a single identifiable "headman." Nowhere was there a body whose members separately or collectively had authority over all inhabitants of the settlement. What existed was not authority but personal leadership. There were and are in every Kalinga settlement some individuals whose exceptional prowess in combat or whose superior wealth or wisdom gave them influence not only over their immediate family members but over many of their more distant kinsmen as well. When one of these self-made leaders decided upon some course of action, a cluster of persons made up

${ }^{11}$ Fred Eggan, "The Sagada Igorots of Northern Luzon," in Social Structure in Southeast Asia, ed. George Peter Murdock (Chicago: Quadrangle Books, 1960), pp. 27-30. Similar groups are found among the Muslim Maranao of the Southern Philippines, but not among the Christian peoples of the islands. See Melvin Mednick, Encampment of the Lake: The Social Organization of a Moslem-Philippine (Moro) People, Philippine Studies Program, Department of Anthropology, University of Chicago, Research Series, No. 5 (Chicago: University of Chicago Philippine Studies Program, 1965). 
of his family and of these more distant kinsmen-followers were likely to support him. And when all of the leaders of substantial personal followings could agree on some course of action-a rare occurrence in any case-a large proportion of the settlement could be mobilized into action-but not the entire settlement. For while not everyone could be a leader, no one was obliged to be a follower. There was always the option of being an independent individual who neither led nor followed any man, and it was the presence of such individuals, as well as frequent disagreement among leaders, that made communitywide action extremely hard to achieve.

Further, community action was of an extremely limited sort, being concerned mainly with such matters as defense against raiding parties from other settlements. It fell far short of "government." There was no law making, no tax collection, no arresting of accused persons by policemen, no courts, and no public executioner. Killing and other wrongs were torts against individuals and their kindreds, not crimes against the community, and they were dealt with by individuals with the assistance of their kinsmen, and the help of neutral mediators. Under such conditions justice varied, depending upon the relative ferocity of the two antagonists and the size of the kindred which each could mobilize in his support.

While the Kalinga lacked territorial authority, even at the local level, they at least recognized the existence of discrete geographic boundaries between neighboring settlements. Not so the Ifugao, another pagan tribe living nearby. Among the Ifugao, Barton reports, geographic boundaries were vague and shifting. Each "region" or settlement was viewed by its inhabitants as the center of a series of concentric rings which Barton calls respectively the "home region," the "feudist zone," and the "war zone," terms which suggest the decreasing restraints upon violence toward people who live at increasing distances from one's home. The Ifugao had no common conception of a larger territory subdivided into districts or similar units. Zones structured territory as the kindred structured people: in terms of distance from ego or ego's place of residence. Barton, citing Henry Sumner Maine, assumed the absence of discrete territorial boundaries to be a fairly primitive trait. But as will be noted in several of the later cases, a dearth of discrete boundaries or of organization based upon such boundaries, is characteristic of some more advanced polities as well and seems to be consistent with their preference for dyadic structures.

Because the Kalinga, in contrast to the Ifugao, recognized discrete territorial boundaries, they were able to create an interregional network of "peace pacts" which, though essentially dyadic, had some relationship to territory. Until recent times the absence of roads, the virtual restriction of marriage to members of the same locality, and the danger of being killed if one ventured far from one's home region served as a strong deterrent to interregional travel. With the construction of roads through the mountains by the lowland colonial government during the nineteenth and twentieth centuries, travel between regions became easier while the possibility of profit making through interregional trade provided incentives for such travel. To assure their safety when visiting each others' regions, pairs of native traders established trading partnerships through which each partner gave food and lodging to the other and, more important, promised to avenge him as he would avenge his own kinsmen should the other be killed by someone in that region. During the latter part of the nineteenth century, this institution which initially had given protection only to the two partners, became transformed into a more elaborate system under which two "pact holders" living in different regions undertook each in his own region to avenge any traveler from the other's region who met violence while visiting there. Individual protection thus became blanket protection, but was still anchored in individuals. It was the pact holder assisted by his personal kindred, and not the region, which offered protection. It was the pact holder who paid compensation if he failed to avenge, and who collected compensation if the other pact holder failed to do so. And if a pact holder died, and no one else came forth to take his place, the pact lapsed and with it the possibility of safe travel between the two regions. Furthermore, each two of the many regions of Kalinga had-or did not have-their separate pacts with each other, and for each pact affecting a region the pact-holder might be a different individual. The complex of pacts thus was a network, not an association. Finally, whenever a new pact was negotiated, any individual in either pact holder's region who had an unsettled blood-debt to avenge in the other region could assert the right to be excluded from the coverage of the pact.

Thus the Kalinga were never able to devise what to foreigners might seem a much more logical, effective, and categorical solution to the problem of individual security: the establish- 
ment of a Kalinga-wide confederation guaranteeing everyone protection everywhere. The system was as primitive, and as dyadic in structure, as was the international community of powers prior to the establishment of the League of Nations.

\section{The Tausug}

The second Southeast Asian political system is that of the Tausug, a Moslem ethno-linguistic group of some 325,000 persons who live in the Sulu island chain which links the main Southern Philippine island of Mindanao with Northern Borneo. Roughly half of the Tausug reside on the largest of the Sulu islands, Jolo. The Tausug have a cognatic kinship system with a slight patrilineal bias which is attributable to the influence of Islam. Most of them live in scattered upland settlements where they engage in intensive dry rice farming. The description and explanation of Tausug political institutions presented here is taken entirely from the studies of Thomas M. Kiefer, an anthropologist. ${ }^{12}$

Unlike the rest of the territory of the present Republic, the Southern extremities of the Philippine archipelago, including Sulu, never came under the effective rule of the Spanish colonial regime. Foreign military subjugation of its "Moro" inhabitants was accomplished only during the American colonial period. Even now the authority of the national government in this region is uncertain. The Tausug continue to deal with their own affairs, and in particular to settle their own disputes, largely through traditional political institutions. Thus the Tausug, though nominally Filipinos, retain a political culture and a largely autonomous political system which are premodern in nature and which have more in common with the culture and polity of traditional Moslem Indonesia and Eastern Malaysia than with those of the long Christianized majority of the Philippines.

Except for some now moribund functions of the sultan, Kiefer's description is of Tausug political institutions as they function today. These institutions are of interest here because, as Kiefer observes:

\footnotetext{
${ }^{12}$ Thomas M. Kiefer, "Institutionalized Friendship and Warfare among the Tausug of Jolo," Ethnology 7 (July, 1968), 225-244; and Tausug Armed Conflict: The Social Organization of Military Activity in a Philippine Moslem Society, Philippine Studies Program, Department of Anthropology, University of Chicago, Research Series, No. 7 (Chicago: University of Chicago Philippine Studies Program, 1969); The Tausug: Violence and Law in a Philippine Moslem Society (New York: Holt, Rinehart and Winston, 1972).
}

Corporate groups on all planes of society except the ultimate level of the sultan, are distinctly secondary to dyadic social relationships. ${ }^{13}$

and:

The Tausug seem to have taken the pervasive Philippine indigenous institution of dyadic ritualized friendship and used it as a major foundation for the establishment of a state based on Islamic models, without having developed the geographically defined units of . . . more politically centralized societies. ${ }^{14}$

In contrast to the Kalinga, the Tausug, prior to the imposition of American colonial rule during the second decade of this century succeeded in creating an incipient state. They shared a conception of a supralocal community with a common body of law and a collection of offices differing in their dignity and the spatial extent of their authority. These offices reached their apex in the office of the sultan.

This community, its law, and its offices survive today. The sultan in recent years has lost many of his old duties. Not so the local headmen-leaders who are the main subjects of Kiefer's study, and are of special interest from the point of view of the dyadic model. These functionaries continue to play a number of important roles-the nature of which can be explained in part by certain features of Tausug culture.

Like the political culture of the Kalinga, that of the Tausug places a high value upon the personal defense of honor and property. This encourages a high incidence of both violence and litigation. Vengeance killing in the pursuit of private feuds is endemic. The obvious parallels with Kalinga feuding suggest that this is a preIslamic element of Tausug political culture. At the same time, Kiefer notes, the Tausug seek order and a sense of community through their common acceptance of a Tausug version of Islamic law.

Out of these contrasting values arises a need for figures of superordination who are adept both at peacekeeping through the enforcement of the law, and at the type of violent action demanded by feuding. Both tasks are performed by men whom Kiefer describes variously as headmen or as leaders.

That part of Tausug ideology which the Tausug themselves believe to be Islamic in derivation requires that every Tausug be subject to the law. More precisely, it requires that he be subject to an individual capable of acting as

\footnotetext{
${ }^{13}$ Kiefer, Tausug Armed Confict, p. 189.

${ }^{14}$ Kiefer, Tausug Armed Conflict, p. 192.
} 
"the law," a person who has the authority to adjudicate, arbitrate or mediate, and the physical means to see to it that the outcomes of such legal actions are obeyed. The substance of this law is laid down in written form by each reigning sultan. The authority to enforce it, i.e., to act as "the law" is also bestowed by the sultan through the awarding of one of a variety of ranked secular or religious titles, though this function of the sultan now is performed less frequently than formerly.

But subjection of individuals to specific superordinates qualified to act as "the law" involves a substantial element of individual consent. While some titles are claimed through inheritance, they are in practice awarded only to those who have been able to gain acceptance as leaders. Furthermore, a headman's authority when it has been given formal sanction by the sultan, remains confined to those who are willing to be subject to it. This means that headmanship is not, strictly speaking, territorial. Receipt of a title, Kiefer reports, "does not necessarily guarantee to the holder any particular territory which is exclusively his own and distinct from that of any other office holder."15 It has more the character of a license to practice law than of judicial authority over a specified bailiwick. Yet it does have a limited spatial aspect: Usually in any local settlement there will be found but one title holder. In the general vicinity of his domicile, his authority, legal and otherwise, is strong and nearly exclusive. The requirement that every Tausug be subject to some title holder qualified to act as the law, and the awesome proximity of a popular headman would seem to encourage acceptance. But with increasing distance from his place of residence, the proportion of individuals who decline to accept his authority in legal matters or who divide their allegiance between him and the headman of a neighboring settlement increases. Furthermore, his power to adjudicate declines with increasing distance, and only the ability to arbitrate or mediate remains. Finally, the range of his authority and influence may expand and contract during the course of his lifetime, and differ markedly from that of previous headmen who had the same place of residence. ${ }^{16}$

When disputes arise between the subjects of different headmen, they usually can be arbi-

\footnotetext{
${ }^{15}$ Kiefer, Tausug Armed Conflict, p. 36.
}

${ }^{16}$ Kiefer concludes, "Territoriality . . . is not generally conceived in terms of boundaries which create discrete spatial units, but rather in terms of the space which vaguely surrounds a single point." Kiefer, Tausug Armed Conflict, p. 31. trated by a higher title holder. But many disputes, it appears, are not settled through such peaceful means. Often disputes lead to violence which may turn into large scale warfare. And then Tausug headmen, especially the younger among them, assume different and more partisan roles as leaders of small bands of men of fighting age whose function is to support their members in their private feuds with nonmembers. Indeed, it is leadership of such armed bands that gives them the raw power needed to qualify as agents of the law in the Tausug state. ${ }^{17}$ These armed followings in turn are but elements of larger fighting alliances which are made necessary by the Tausug dedication to feuding and to war.

Kiefer examines this system of fighting alliances in detail. In describing its structure he begins with simple dyadic relationships of friendship and of leadership and followership. For this purpose he employs a formal model of dyadic interaction based upon a model I had presented in an earlier publication. ${ }^{18}$ Alliances for mutual aid between leaders of personal followings in turn are used to create ad hoc combinations of increasing size, culminating in maximal alliances which may stretch across an area spanning the whole Sulu archipelago, and pit themselves against equally extensive opposing alliances. At all levels except that of the sultanate itself, Kiefer finds "dyadism" to be the most striking structural feature of the ${ }^{-}$system. Indeed, dyadism manifests itself even in the heat of battle, where each combatant directs his fire with a due regard for the nature of his connection with, and the degree of his enmity toward each member of the opposing side. ${ }^{10}$

While using the same structural devices as the Kalingas, the Tausug in their alliances are able to mobilize much larger numbers of fighting men for individual engagements. The reason for this is clear. The Kalinga, in pursuing what remain purely private feuds, rely for support upon a relatively small number of actual kinsmen. The only exception to this rule is the peace pact, a recent invention which through the establishment of compacts between unrelated pact holders in different regions offers protection to individual travelers far from home. The Tausug have moved to a higher stage of both integration and conflict. Sharing a sense of membership in an incipient state, which brings with it a general interest and involvement in the power struggles of great men, and being far more mobile than the mountain-

\footnotetext{
${ }^{17}$ Kiefer, Tausug Armed Conflict, p. 37.

${ }^{18}$ Kandé, Leaders, Factions, and Parties, pp. 141-148.

${ }^{19}$ Kiefer, Tausug Armed Conflict, pp. 167-171.
} 
bound Kalinga, the Tausug have created large alliances for the pursuit of civil and external war. For this, ties between kinsmen are not enough. Therefore, they have learned to make extensive use of interpersonal alliances of friendship and ritual kinship formalized through the common Muslim Filipino custom of swearing together on the Koran.

To sum up, in a society where discrete descent groups, voluntary associations, and territorial units are lacking, relationships of superordination and subordination are highly personal, and to a large degree voluntary. The span of a superordinate's authority has no clear cut boundaries either in terms of territory or population groups. Thus as in Kalinga, dyadic structure is superimposed upon both space and society.

\section{The Monarchy of Premodern Thailand}

The next example of a Southeast Asian political system is that of a fully developed monarchy. The case employed for this purpose is the absolute monarchy of Thailand from the beginning of the reign of King Trailokanat (1448 AD) in the latter part of the Ayudhya period, until the accession of King Chulalongkorn (1873) which marked the end of the early Bangkok period. This monarchy had a strong ruler, and performed a wide variety of administrative tasks. Nonetheless it relied heavily upon dyadic structure in performing them.

The institutions of the monarchy underwent many changes during the four centuries from which information is drawn. But the features to which I call attention retained their essential character throughout most of this time. My main sources are two historical reconstructions, one focusing upon the Ayudhya period and based largely on legal texts, by $\mathbf{H}$. G QuaritchWales, the second dealing with the early Bangkok period, and based on a broader spectrum of contemporary records by a Thai scholar, Akin Rabibhadana. ${ }^{20}$

Like almost all of Southeast Asia prior to the twentieth century, premodern Thailand had a population much smaller than that which could be supported by the available land. This was especially the case because the population of Thailand, like most of lowland Southeast Asia, cultivated irrigated rice, a grain which produces a very high yield for a given amount of land.

${ }^{20} \mathrm{H}$. G. Quaritch-Wales, Ancient Siamese Government and Administration (London: Bernard Quaritch Ltd., 1934); and Akin Rabibhadana, The Organization of Thai Society in the Early Bangkok Period, 17821873, Cornell University Southeast Asia Program, Data Paper No. 74 (Ithaca: Cornell University Southeast Asia Program, Department of Asian Studies, 1969).
The surplus of land meant that most of premodern Southeast Asia, in the words of Georges Condominas, consisted of a scattering of cultivated islands of population set in an empty but potentially cultivable jungle. As a result, Rabibhadana argues, manpower was more in demand than land. This had important political consequences. One of these consequences was that in mainland Southeast Asia the main purpose of warfare was the capture of populations with a view to settling them on uncultivated land in the environs of the conqueror's capital, rather than the acquisition of new terrain in distant places. This meant in turn that from a ruler's point of view the effective mobilization of his own subjects for attack and defense in time of war was essential to the survival of his realm, while the demarcation of precise jungle boundaries between his and the neighboring realm was of less importance. ${ }^{21}$

This favorable ratio of men to land may have encouraged the growth of structural and normative patterns useful for the maintenance of control over people: Patron-client ties imposed by the state, obedience, deference, the repayment of favors on the part of those subject to the power of others, and the possession and conspicuous display of large personal retinues on the part of the powerful. ${ }^{22}$

Students of Thai history are in some disagreement as to the structure of the Thai political system during the first century of the Ayudhya period and the Sukhothai period which preceded it. As early as the time of King Trailokanat, however, most of the realm was under direct royal administration through governors appointed by the king, though some outlying areas were in the early part of the period under the largely independent but nonhereditary control of certain princely kinsmen of the king. In the capital there were established a number of departments of government called krom. During the early portion of the period these krom with few exceptions were under the effective or titular headship of high ranking princes or princesses. Commoner officials staffed their lower levels, and during the Bangkok period often rose to krom headships. Nonetheless, the princes and princesses as a group maintained their positions of privilege well into the present

\footnotetext{
${ }^{21}$ Rabibhadana, p. 53.

22 Rabibhadana notes, pp. 119-120, that the large volume of historical legal documents concerning disputes over the control of manpower contrasts sharply with the dearth of similar documents dealing with disputes over land. For a discussion of Thai retinues today, see Lucien M. Hanks, Jr., "The Corporation and the Entourage: A Comparison of Thai and American Social Organization," Catalyst (Summer, 1966), pp. 55-63.
} 
century. Indeed resentment of these privileges by Western-educated commoner officials was one of the causes of the palace revolt of 1932 which ushered in the present system of government.

The main administrative tasks of the premodern Thai monarchy consisted in peacetime, of public works construction, and in wartime of the organization of large scale military activity. The labor involved in these efforts was provided by the mass of the king's subjects. It is the manner in which this labor was mobilized and directed that is of special interest here, for it was managed through an elaborate system of patron-client arrangements which endured with but minor modifications from the fourteenth to the nineteenth century.

The earliest references to such a system are for the year 1356 , when by a royal command everyone was required to register under a leader. Those who failed to do so were to be registered directly under the king. ${ }^{23}$ It was under such leaders or patrons (nai) that service to the king was to be performed by those who were registered as their clients (phrai). The nai were thus in effect officials of the state, and this soon came to mean that for those who were not princes or princesses, and thus were not entitled to have clients as a matter of right, an appointment to an official post became a prerequisiteand a license-for the enlistment of clients.

The system was actually a pyramidal one. Lesser officials who had clients of their own were in their turn the clients of higher officials, and all officials above a certain grade, whether they were princes or not, were the direct clients of the king to whom they pledged personal allegiance.

Although this officially created patron-client tie entailed quite specific government-related duties, it appears to have included a broader, more diffuse set of mutual obligations as well. Aside from service to the state and the patron's legal responibility to deliver his client to the courts and defend him there if he was charged with a crime, it involved, as do patron-client relationships in most premodern societies, a broad range of supervisory and protective responsibilities on the part of the patron who in turn could dispose of substantially more of his clients' time than that which they owed the state.

Eventually the system became quite complex. For those outside the ranks of the nai, three distinctive alternative forms of subordination were recognized by law. All of these involved attachment to a specific superordinate.

${ }^{23}$ Rabibhadana, p. 20.
Some clients were attached for their government service directly to a princely or bureaucratic superior. Others were attached directly to the king. $\mathrm{He}$ in turn assigned them to perform their service under specific officials who thus had both direct and royal clients working under their direction. Finally, a substantial number of Thai, estimated by a nineteenth-century European observer to comprise one-fourth of the population, were bound to specific members of the princely and bureaucratic elite not as government service clients but as private debt bondsmen. ${ }^{24}$

The subordination system described here is thus a classic example of vertical dyadic structure. ${ }^{25}$ As might be expected in a system so organized, conflict between the king and the lesser power-holders of his realm took the form of a struggle over the right to control and make use of manpower more than over the possession of land. ${ }^{26}$ In this struggle the nai, led by the great princes were for a time the stronger. As royal clients were wholly the king's men, their annual periods of corvée service were longer than those which could be demanded of direct clients of officials, a portion of whose time belonged to the latter for their private disposal in lieu of what in modern times would have been their salaries, or of debt bondsmen who had the heaviest nonofficial demands on their time. As many commoners had at least some choice in determining their own status, their patrons encouraged them to choose direct clientage or, ideally, debt bondage. The patrons did this by securing for their direct clients or

${ }^{24}$ Debt bondage, which varied in its degree of unfreedom from merely nominal mortgaging of the debtor or a member of his family, through actual debt service, to hereditary slavery, was encouraged by the rule that a patron had a first right to extend loans to his government clients. If a debtor defaulted in his repayments, he could be transformed from a government client into the patron's private debt bondsman, the degree of his unfreedom depending upon the extent of this indebtedness.

${ }^{25}$ Whether the obligation of clientage was confined to men, or applied to both men and women is unclear. Some comments by Wales suggest the latter. See his observation, p. 53 that "When the parents belonged to different kroms, or had different patrons in the same krom, their children, on reaching the age at which government service was required of them, were divided between the patrons of their parents." Other descriptions of Thai clientage make no reference to women. But women it appears, were sold into slavery. Almost all men, at least, of nonelite status were obliged to assume one of these roles of subordination, according to the observation of an early nineteenth-century foreign observer, mentioned by Rabibhadana, p. 81; this foreigner noted that free labor did not exist, for the labor of every individual was appropriated by one or another chief, without whose approval he could not work.

${ }^{26}$ Rabibhadana, pp. 36-39, 56-59. 
debt bondsmen increased (and sometimes total) exemption from government service, and by making private service less onerous than government service. ${ }^{27}$ This alienation of royal clients during the latter years of the Ayudhya period contributed, in the opinion of Rabibhadana, to the weakening and defeat of the state at the hands of the Burmese. Subsequent rulers at Bangkok reversed the trend and increased their control of manpower by lessening the burdens of royal clients while decreasing the exemptions from corvée service of private clients and debt bondsmen, and by requiring that all clients be tatooed with the names of their patrons and their towns of residence. ${ }^{28}$

One aspect of the traditional Thai system has special importance for an understanding of the functioning of dyadic structures and of the conditions under which they can be expected to be prominent: A question on which Thai specialists have been in some disagreement is whether the krom of premodern Thailand were territorial units, functionally specialized units, or a mixture of the two. The historical materials presented by $\mathbf{H}$. G. Quaritch-Wales suggested to him and to others who have accepted his interpretation, including Vella, Mosel, and Siffin, that an earlier "feudalistic" territorial form of organization was replaced in King Trailokanat's time by a system of centrally directed krom that in the words of Mosel, "tended to have both territorial and functional responsibilities, which in time led to considerable confounding and overlap." 29

\footnotetext{
${ }^{27}$ Under Ayudhya law, as reported by Wales, p. 5, commoners were entitled to choose and leave their patrons. That in practice this right was always preserved seems unlikely. A decree by King Rama II quoted by Rabibhadana, p. 88, which promised runaway clients that if they returned from the jungle "this time only they would not be punished and would be allowed to choose their new patrons," attests to this. On the other hand Rabibhadana reports, pp. 34-35, that it was fairly easy, prior to the institution of tatooing of clients, for a dissatisfied client to abscond and have himself secretly taken in by another patron, or find another patron who would buy him from his first master, or by lending him money convert him into his debt bondsman.

${ }^{28}$ Rabibhadana, pp. 38, 59. The alienation of royal clients by princely patrons and the consequent weakening of royal authority recalls a somewhat similar development which took place in Japan during the several centuries which followed the first attempt to establish a centralized bureaucratic state in the seventh and eighth centuries. In the Japanese case however the development involved the control of land and only secondarily the enlistment of manpower. See George Sansom, A History of Japan to 1334 (Stanford: Stanford University Press, 1958), pp. 83-89.

${ }^{29}$ James N. Mosel, "Thai Administrative Behavior," in Toward the Comparative Study of Public Administration, ed. William J. Siffin, (Bloomington, Ind.: Indiana University Press, 1957), p. 287. Rabibhadana, pp.
}

Fred Riggs, drawing on Heine-Geldern, has attempted to account for this apparent structural confusion by suggesting that late Ayudhya krom were designed to be neither territorial nor functionally specialized entities but rather to be "cosmological and topological" units which would conform to the requirement, derived from Indian religious belief, that the realm, like the palace at its center, be arranged in accordance with the directions of the compass. Territorial or functional responsibilities or both were then assigned to these units, Riggs argues, as convenience dictated. ${ }^{30}$ Riggs's suggestion that krom were designed to be something other than territorial or functional units seems reasonable, but a cosmological explanation of this fact seems unconvincing as more than a partial explanation. I find more persuasive the interpretation of Rabibhadana, which was foreshadowed by Hanks, that the krom were intended primarily to be units of manpower. ${ }^{31}$ If this interpretation is correct, then the aim of the monarch in establishing the krom would appear to have been a dual one: to attain tight control over a maximum number of his subjects, and to make use of, but at the same time limit, the power of his princely kinsmen. Given the man-land ratio of premodern Thailand and the values and forms of organization which this encouraged, as well as the rule of declining princely descent, the most efficient method of achieving these overarching goals was to attach individuals to individuals in a great pyramid of centrally controlled nonhereditary patron-client arrangements. ${ }^{32}$ The assignment to such units of designations which satisfied cosmological, functional,

29,31 , notes that, legally, towns were equated with $\mathrm{krom}$, and that governors were equated with chiefs of krom.

${ }^{30}$ Fred W. Riggs, Thailand: The Modernization of a Bureaucratic Polity (Honolulu: East-West Center Press, 1966), pp. 70-72, 79; and Robert Heine-Geldern, Conceptions of State and Kingship in Southeast Asia, Cornell University Southeast Asia Program Data Paper No. 18 (Ithaca: Cornell University Southeast Asia Program, Department of Far Eastern Studies, 1956), pp. 3-5.

${ }^{31}$ Rabibhadana, p. 77. Hanks, who is quoted by Rabibhadana has described the premodern social order of Thailand as one "which resembles a military organization more than an occidental class type society." Lucien M. Hanks, Jr., "Merit and Power in the Thai Social Order," American Anthropologist, 64 (December, 1962), pp. $1247-1261$; cited at 1252 .

${ }^{32}$ Under the rule of declining princely descent, a king's numerous male descendants by his many wives could pass on their rank to their descendants only in diminished form. The sixth generation became commoners. A king's female descendants could receive rank but could not transmit it even in diminished form. This would seem to have discouraged the creation of stable heritable princely clienteles. 
or territorial needs would have been a matter of little difficulty.

Some evidence that supports this interpretation, presented by Rabibhadana, includes his finding that new krom frequently were created to provide positions and clients for specific princes and princesses, and conversely that on the death of a prince his clients often were transformed into royal clients and the krom as a whole, consisting of both clients and lesser officials, converted into a sub-krom and attached to another major krom. $^{33}$

But the contrary interpretation, that krom were more than transitory unspecialized aggregations of manpower, is supported by the fact that various $k r o m$ did have names indicative of specific functions. And further ambiguity is added because during some periods at least, when a high personage lost his krom, his direct clients remained with him and could be inherited by his descendants, while his royal clients stayed with the krom. ${ }^{34}$

It appears, then, that there is no single way of describing a $\mathrm{krom}$ in premodern Thailand. It seems to have been a catchall term used to describe various kinds of units including the personal retinue of a prince, a troop of soldiers under an appointive nonprincely commander, and a rough territorial jurisdiction defined as much by its inhabitants as by precise geographic boundaries. In later years it came to mean a functionally specific department of the central government. But clearly even in quite recent times, many krom were designed at least in part to provide support groups and a living for the great men and women of the realm.

The advantages of a system of administration employing movable entourages is obvious. The leader with his clients can be shifted about without being allowed to develop the strength that is to be derived from a fixed territorial base. Yet he is made a useful agent of the king by being given a body of men personally loyal to himself-an essential ingredient of effective administration in premodern societies. If he proves his loyalty to the king, he can be allowed to increase the size of his following. If his loyalty is in doubt, his retinue can be decreased or taken from him, or he can be made subordinate to a more trusted leader, or sent off with his men to some distant place. This type of organization is possible, however, only in a state which can dispense with complex and stable territorial organization, and one in which the need for a high degree of functional specialization at the center has not yet developed.

Rabibhadana, pp. 31, 78.

${ }^{34}$ Rabibhadana, pp. 30-31.
This, it appears, was the case in premodern Thailand.

Patron-client relationships described here for the late Ayudhya and early Bangkok periods, continue to be among the main building blocks of the Thai society and polity today. David Wilson has given us the classic description of how great personal followings serve as the support groups of individual members of governing "coup groups" both in the Thai bureaucracy, military and civilian, and in Parliament. Fred Riggs has examined the same subject further, and in addition has explored patron-client relationships between high Thai officials and Chinese pariah capitalists on the one hand, and between such officials and the organizers of various voluntary associations on the other. William Siffin has explored the same subject in the sphere of administration. Finally, various nonpolitical scientists, aside from Hanks and Rabibhadana, including James Mosel and Herbert Phillips, have noted the importance of personal alliances in nonpolitical spheres of contemporary Thai society. ${ }^{35}$ Their findings will not be summarized for Thailand is employed here as the example of a premodern monarchy.

\section{The Modern Philippines}

For analysis of a modern system which makes much use of dyadic structures and techniques, a society with yet another religious tradition may be examined: that of the predominantly Christian, Hispanized, and Americanized Republic of the Philippines.

The Philippine case is based upon my own past and ongoing research. A more detailed discussion of Philippine politics may be found elsewhere. ${ }^{36}$ The Philippine political system is set within a political culture which may be described as follows: The individual sees himself in an unpredictable, competitive world in which his first concern must be with his own welfare and that of his immediate family. In the pursuit of self and family interest he finds himself in conflict with others. This leads to mistrust and envy. It also leads to the placing of a high value upon the achievement of power and dominance, which places him beyond the reach of

\footnotetext{
${ }^{25}$ David A. Wilson, Politics in Thailand (Ithaca: Cornell University Press, 1962); Riggs, "Thailand"; William J. Siffin, The Thai Bureaucracy: Institutional Change and Development (Honolulu: East-West Center Press, 1966); Mosel, "Thai Administrative Behavior"; Herbert P. Phillips, Thai Peasant Personality: The Patterning of Interpersonal Behavior in the Village of Bang Chan (Berkeley: University of California Press, 1965).

${ }^{36}$ Landé, Leaders, Factions, and Parties; and Southern Tagalog Voting: Political Behavior in a Philippine Region, A.I.D. Research Paper (January, 1972).
} 
the envious and allows him to advance his interests with a minimum of external interference. ${ }^{37}$

The individual and his family need not, however, face the competitive world alone. They can form alliances with others for the purpose of mutual aid. Power and wealth are useful in the building of such alliances. The ideal is to have many allies which maximizes one's security. Alliances are built not only for the dyadic exchange of aid but also for the establishment of a common front against outsiders which allows a successful combination to appropriate a disproportionate share of the available benefits. Combinations can vary in size, expanding or contracting in accordance with the size of the arena and the size of the largest opposing combination. Old allies can quickly become opponents in a struggle over the allotment of the rewards of their earlier collaboration. In such a setting a high value is placed upon the redistribution, among followers and allies of any member of a combination, of benefits which he may obtain.

Though Philippine society is highly competitive, there exists, nonethless, an awareness of a broader community-wide interest and a yearning for community-wide harmony. While skeptical of the practicality of achieving a general increase in wealth through collective action, and dubious about the possibility of achieving exact justice through the equalization of benefits, Filipinos realize that no important individual or group will accept permanent exclusion from access to benefits, and that peace within the community requires that none be permanently excluded. Inclusion is achieved not through equalizing policies but through the rotation of benefits over time. Letting other people "have their chance," like redistributive sharing, is thus seen to be essential to social harmony.

Philippine political culture thus has some similarities with those of the earlier political systems, but it differs from them as well. Though "individualistic" to the point of disorder, it is not anarchic to the same degree as those of the Kalinga and Tausug. Though highly inegalitarian, it lacks the harsh authoritarianism of premodern Thailand. Finally, while it provides a setting appropriate for a heavy reliance on dyadic action, it also offers

${ }^{37}$ For excellent discussions of behavior and its structural basis in societies not very different from that of the Philippines, see Edward C. Banfield's classic The Moral Basis of a Backward Society (Glencoe: The Free Press, 1958); and more recently Jane Schneider, "Of Vigilance and Virgins: Honor, Shame and Access to Resources in Mediterranean Societies," Ethnology, 10 (January, 1971), 1-24. hope to aspirations for collective action for the common good.

Structurally, the Philippine political system viewed from the top downward, appears to be composed mainly of discrete entities: There are a wide variety of occupationally specialized voluntary associations. There are two nationwide political parties which biennially run slates of candidates for a wide variety of elective offices. There is a Congress, both of whose houses usually though not invariably organize themselves at the beginning of each session on party lines. There are departments and agencies of government staffed largely by those who have passed civil service examinations. And there is a system of courts. All of these political and governmental structures function in part at least as do their American counterparts.

But in other ways, which seem puzzling to American observers, these structures operate in a manner not easily explained by the group theory of politics. Associational and institutional interest groups account for only a small part of the totality of interest articulation. The two major parties are identical in their social composition and do not present distinctive or even distinguishable programs to the electorate. Party switching is endemic, as are cross-party alliances for control of the government. Two presidents of the Republic, since Independence, switched parties shortly before being elected. Repeatedly in the House of Representatives disloyal members of one party have helped to overthrow their party's speaker by joining with the opposite party to install one of the latter's members in this powerful post. Twice in recent years members of one party helped the opposite party retain the speakership with the tacit support of their own party's chief executive. Members of the bureaucracy, on the whole, show but limited regard for formally established lines of authority, while judges often are suspected of deciding cases with less than strict impartiality.

Some reasons why this system operates quite differently from the American one, whose macro-structures it seems at first sight to duplicate, begin to appear when one examines the Philippine political system not from the top downward but from the bottom upward. One then discovers that it makes as much use of nondiscrete as of discrete structures. For the performance of certain tasks it relies heavily, though not of course exclusively, upon a great net of dyadic alliances, some of them horizontal but more of them vertical, leading inward and upward from the villages to the national govern- 
ment, from "little people" to "big people," and from those who have favors to ask or demands to make to those who have the power to grant them. This network of alliances often shows little regard for the boundaries which separate discrete structures, whether they be interest groups, parties, or the various instrumentalities of government. And in performing its various tasks, the Philippine political system proceeds as much through particular decisions affecting specific individuals, and based on the principles of favoritism and the quid pro quo, as through categorical decisions applied impersonality and impartially in accordance with the law. In short, the Philippine political system makes use of both discrete and dyadic structures in a mix which contains a substantially larger component of dyadic structure than does its American counterpart.

The nature of this Philippine mixture can be seen in the way the system performs two major tasks: the election of public officials and the processing of the public's demands for governmental outputs. I shall discuss each of these two tasks and the structures which perform them separately.

The most striking feature of elections in the Philippines is the strong disposition of the mass of ordinary citizens to vote for "personalities" rather than political parties. Clear evidence of this was found in the course of analyzing the contents of a large number of ballots taken from ballot boxes in ten sample precincts of a typical province after the off-year elections of 1963. These showed that in the average precinct, 74 per cent of the ballots were crossparty ones, i.e., contained votes for candidates of more than one party. ${ }^{38}$

The cross-party voting habits of the electorate have their counterpart in the campaign techniques of candidates for elective offices. These find it necessary to build what are essentially personal campaign organizations. In this they seek the help of lower level political leaders who have personal followings whose votes they can deliver, and of candidates for even higher offices who are willing to help finance the candidate's campaign in exchange for aid in their own search for votes. In both cases, their main concern is to find strong allies, without much regard for their party identification. Thus many such alliances cut across party lines.

Formally, each party is an association composed of those who have become party mem-

${ }^{\text {ss }}$ For a report on the analysis of these ballots, see Carl H. Landé, "Parties and Politics in the Philippines," Asian Survey, 8 (September, 1968), pp. 242-247; and Southern Tagalog Voting, pp. 81-93. bers. In practice each party, at any point. in time, is a multi-tiered pyramid of personal followings, one heaped upon the other. Each link in the chain of vertical dyads is based upon personal assurances of support and conditional upon the downward flow of patronage and spoils. But even this description of a party exaggerates its coherence. For as has been noted, political leaders wander into and out of parties with their personal followers in tow, feeling no strong obligation, and being under no real pressure, to support their party mates. Party membership is not a category but a matter of degree. ${ }^{39}$

If one wishes to discover the real framework upon which election campaigns are built, one must turn away from political parties and focus one's attention upon individual candidates and the vertical chains of leadership and followership into which they arrange themselves of any given point in time. While tending to tie together persons who claim the same party label, these chains must in fact be viewed as independent structures resembling a network of strong vines which variously cling to or twist back and forth between two great but hollow trees.

The personal basis of political loyalty helps to account for the types of individuals who win elections. Victory tends to go to those with the greatest personal wealth, to those with the most flamboyant campaign styles, and to those who are thought most likely to be able to win and thus to have access to patronage and other rewards of office. A candidate's position on questions of ideology or his loyal support of such as there is of party policy appears to be of minimal importance.

When one inquires into the way the public's demands for governmental outputs are processed in the Philippines, one finds that less use is made of the "primary" ties of kinship and patronship-clientship than was the case in the contesting of elections, and more use is made of ties arising out of considerations of specialized economic interest. But such arrangements insofar as they are employed, also are in large part dyadic.

In Almond's reworking of the "group theory" of politics into the framework of a political sys-

\footnotetext{
${ }^{39}$ For case studies of local and provincial politics which illustrate these points, see Mary R. Hollnsteiner, The Dynamics of Power in a Philippine Municipality (Quezon City: Community Development Research Council, University of the Philippines, 1963); Remigio E. Agpalo, Pandanggo-Sa-Ilaw: The Politics of Occidental Mindoro, Papers in International Studies, Southeast Asia Series, No. 9 (Athens, Ohio: Ohio University Center for International Studies, 1969); and Landé, Leaders, Factions, and Parties, pp. 132-140.
} 
tems model, the demands of individual citizens, in a more developed polity are satisfied through a series of consecutive "conversion processes," performed by a number of specialized structures. Conversion as it goes through its several stages involves the progressive transformation of the particular into the categorical, and then into the particular once again. In the end, the individual citizen gets what he wants, or a portion of it, but only as a result of a lengthy process that is designed to assure that all who are like himself will receive the same benefits or be subjected to the same deprivations.

Almond's model of this process fits the Philippines only to a limited degree. Private goals may be attained in disregard of the law by members of all social strata. The powerful, the rich, and the well connected, can obtain favored treatment through personal office holding, through the use or threat of force, or by offering material rewards to bureaucratic decision makers. The weak and the poor often can hope to obtain leniency either by becoming the clients of persons in positions of power or, in the case of those who lack such connections, through appeals for awa (pity) - an appeal which carries much weight in Philippine culture. For those who can obtain governmental favors or exemption from law for themselves, and this includes most of the politically adept members of society, there is little incentive to work for the passage of general legislation. This helps to account for the relatively small part which is played in the interest articulation process by organized interest groups.

The argument should not be overstated. There are in the Philippines many voluntary associations which to some degree resemble American pressure groups, and their number is growing rapidly. ${ }^{40}$ With a few exceptions, however, notably that of the sugar industry, for whose political effectiveness there is a special historical explanation, these groups are small, subject to fission, and fairly short lived. While they do press for general legislation, major portions of their leaders' efforts are devoted to interceding with public officials on behalf of specific individuals and firms. As a result, many such associations are widely thought to be the personal instruments of their leaders whose private interests receive first attention. Ordinary

${ }^{40}$ See Remigio E. Agpalo, The Political Process and the Nationalization of the Retail Trade in the Philippines (Quezon City: University of the Philippines, 1962); and Robert B. Stauffer, The Development of an Interest Group: The Philippine Medical Association (Manila: University of the Philippines Press, 1966). members of the category for which an association professes to speak usually have little to gain through membership unless they have personal ties with the leaders sufficiently close to justify the hope that special efforts at intervention will be made in their behalf. Most individuals find it more to their advantage to cultivate whatever personal connections they may have with any politician who is willing to help them obtain favors.

The nature of Philippine political structure also affects the outcome of the interest aggregation process. Specifically, it prevents the two major parties from offering the electorate a choice between two reasonably coherent and distinctive party programs. The reason for this appears to be as follows: According to Almond's schema, which fits most modern democracies, individual political parties, while representing broader slices of society than do individual interest groups, still seek support mainly from one or another part of the whole spectrum of interests. This permits each party to devise a program that is at least to some degree distinctive and coherent. In the Philippines, however, both major political parties are what Maurice Duverger called "cadre parties," led by members of the elite who in each province and town compete with each other in seeking electoral support from members of all social strata. ${ }^{41}$ They are able to win such support largely through the massive distribution of a broad spectrum of particular rewards appropriate to the private needs of members of all sectors of society. At the same time, leaders in both parties compete with each other in trying to satisfy to some degree at least the broader legislative demands of virtually all articulate interest groups.

This makes both major parties excellent compromises but poor instruments for the formulation of distinctive and consistent programs. Such programs, insofar as they exist at all in the Philippines, are the creations not of parties but of individuals. Each new president when he takes office begins to create his own program. In doing so, he is guided by his personal views, the views of his advisers, and by a variety of pressures from diverse sources which no president can ignore. Each member of the Congress does roughly the same, though many members of both parties respond in some degree to pressure or persuasion from the incumbent president. Thus, the legislative output of the Philippine government is the resultant of

\footnotetext{
${ }^{4 t}$ Maurice Duverger, Political Parties: Their Organization and Activity in the Modern State, 2nd ed. (London: Methuen, 1959)
} 
the individual decisions of numerous legislators, guided to some degree by the president, rather than the handiwork of the dominant political party as such.

However legislation in any case is a less important aspect of the governmental process in the Philippines than in countries where laws are strictly enforced. More important from the point of view of most voters and therefore of most legislators is the way law is enforced-or not enforced-with respect to specific individuals, firms, and localities by administrators.

Members of the Congress influence administrative decisions by threatening to cut departmental appropriations or block promotions, as well as by placing their own proteges in various departments and agencies. One finds therefore a complex network of personal alliances which cut across the formal boundaries between the branches of government. This is the case, of course, in all political systems to some degree, but in the Philippines the pattern is especially marked.

This system of alliances has consequences for the informal operation of the executive branch. Since the proteges of members of Congress are more dependent for their advancement upon the intervention of their extradepartmental patrons than upon the good will of their immediate superiors, bureaucratic discipline is uncertain. Saddled with many uncontrollable subordinates, the wise official responds by attempting to create a personal following of his own among those of his subordinates who show a willingness to give him their primary loyalty in return for the receipt of special favors, and by refusing to delegate authority to any but his personal clients. ${ }^{42}$

${ }^{42}$ The Tagalog term for such a client is bata (literally, "child"). Modern organizations in the Philippines, both in the government and the private sector, are honeycombed with bata systems of the classic patron-client type. Equally widespread are compadre relationships of the type found in Latin America and medieval Europe. These may be either vertical or horizontal. A functionally equivalent tie among Filipino Muslims is that which results from swearing together on the Koran. Finally, in the economic sphere there are to be found suki relationships between buyers and sellers who deal with each other on the basis of favored treatment. The latter type of relationships have been described by James N. Anderson, in "Buy and Sell Economic Personalism: Foundations for Philippine Entrepreneurship," Asian Survey, 9 (September, 1969), 641-668. The "compadre system," which in Latin America is called compadrazgo, has been described by numerous writers. The best comparative discussion is that of Sidney W. Mintz and Eric R. Wolf, "An Analysis of Ritual Co-Parenthood (Compadrazgo)," Southwestern Journal of Anthropology, 6 (Winter, 1950), 341-468. For an excellent survey of various relationships of this sort see Julian Pitt-Rivers, "Pseudo Kinship," in The International Encyclopedia
To summarize: Together with a multistage conversion process, performed by a succession of specialized structures, one finds in the Philippines a much more simple process of favor seeking and favor giving between members of the public and administrative decision makers. This process is carried on through chains of dyadic ties that bypass interest groups, parties and the law-making structures, and therefore lessen the part they play in the country's governance.

A number of consequences follow from this heavy reliance upon dyadic methods of goal attainment:

(1) It provides specific benefits for some members of all sectors of society, thereby minimizing intercategorical, including interclass, hostility, and reducing the bitterness of conflict between the political parties as well as between other organized groups. At the same time, it produces dissatisfaction among those other members of all sectors of society who have not received their share of specific rewards.

(2) By permitting favoritism to undermine the impersonal administration of justice, it contributes to the near anarchy which presently prevails in many parts of the Philippines, and it erodes public confidence in the system of government.

(3) It causes changes in governmental policy to be secular rather than cyclical, for it makes change depend not upon the alternation in power of the two political parties but mainly upon long-term changes in the constellation of forces in Philippine society, as well as upon the accident of an individual president's personal views.

(4) It produces a system whose responsive and distributive capabilities are quite high, but whose extractive and regulative capabilities are exceedingly low.

(5) It makes the mobilization of political support immensely costly both in money and effort. An added cost is the growing conviction among many Filipino intellectuals that holding these highly expensive periodic elections is too high a price to pay for the advantages of democracy.

(6) Finally, it leads to that preoccupation with personalities, offices, and spoils, and that lack of interest in policy or ideology, which is so strikingly characteristic of Philippine politics.

\section{The Four Systems Compared}

Four Southeast Asian political systems, im-

of the Social Sciences, 8 (New York: Crowell, Collier and Macmillan, 1968), 408-431. 
bedded in different political traditions and representing different stages of political modernization, have illustrated the tasks which can be performed by dyadic structures composed variously of ties of kinship, friendship, patronshipclientship and interpersonal political alliances.

It may be asked why these Southeast Asian societies show such a marked tendency to employ dyadic structures in preference to discrete ones. Several possible explanations suggest themselves: One is that the peoples of these societies find models of dyadic structure in their cognatic kinship systems, and therefore are inclined to favor dyadic devices when they build larger structures that embrace nonkinsmen. If this is true, then peoples that have unilineal descent systems, which divide society into discrete clans and lineages, should favor those nonkinship structures that are discrete. I have discussed some cases which illustrate such a transfer of structural principles from the kinship to the nonkinship sphere elsewhere. ${ }^{43}$ And there is statistical evidence of a strong association between the presence or absence of these two types of kinship and that of some other political institutions. ${ }^{44}$ But the argument must not be pressed too far. A growing body of anthropological research shows that peoples with unilineal systems of descent employ various types of dyadic structures alongside discrete descent groups and voluntary associations. In such societies, dyads are used especially to build alliances across the boundaries which separate descent groups so as to free rulers and others from an exclusive dependence upon their lineage and

${ }^{43}$ See Landé, "Kinship and Politics in Pre-Modern and Non-Western Societies."

4 Data from George Peter Murdock's "World Ethnographic Sample" were employed to test the hypothesis that cognatic societies are less likely than unilineal societies to assign positions of political leadership on a hereditary basis. This entailed the construction of a two-by-two table for unilineal versus bilateral (cognatic) descent and for hereditary versus non-hereditary political succession. The number of societies which fit into the table were 384 . Unilineal societies tended to have hereditary political succession approximately four times as often as non-hereditary succession, while bilateral (cognatic) societies were almost equally divided between the two types of succession. The Phi coefficient was .32 , indicating a relatively strong relationship in the hypothesized direction. The Chi square test indicated that the relationship would occur by chance in less than one out of 1,000 cases. Another two-by-two table was constructed for unilineal descent versus bilateral (cognatic) descent and for hereditary slavery versus the absence of hereditary slavery (slavery if present, being only temporary or nonhereditary). This time the number of societies in the table was 464 . While 27 per cent of the unilineal societies had hereditary slavery, only 12 per cent of those with bilateral (cognatic) descent did so. The Phi coefficient was .18. The Chi square clan mates. ${ }^{45}$ And peoples with cognatic systems of kinship in Southeast Asia and elsewhere, as they become more modern, do of course make an increasing use of discrete structures.

There are other possible explanations for the proliferation of dyadic structures of the type described here in these four societies, which are not inconsistent with the previous one. The shortage of manpower in relationship to available land, which prevailed in most of Southeast Asia until quite recently, may have encouraged the development of a variety of simple but effective dyadic devices, ranging from compulsory clientage through debt bondage to slavery, which allow individuals to exploit the labor of other individuals for their private advantage. (In regions where land is scarce the impetus for the creation of patron-client ties probably is more likely to come from below, i.e., from tenants who seek to ensure their access to land.)

The endemic nature of private violence, encouraged by a conception of honor which requires that personal affronts and injuries be avenged by force, may have also encouraged the extension of webs of alliances suitable for defense and offense in private warfare. The steady growth of private armies under the control of warlord-politicians, a neo-feudal development which has characterized the Philippines since independence and is one of the underlying causes of the current crisis in that country, illustrates this point.

Finally, all four societies share a "limited good," "constant pie," or "zero sum" view of the resources available in a community in the sense in which these terms have been applied by George Foster in Mexico and James Scott in Malaya. ${ }^{46}$ Such a view, which perceives anyone

test again indicated the relationship would occur by chance in less than one out of 1,000 cases. The data were taken from George Peter Murdock, "World Ethnographic Sample," American Anthropologist, 59 (August, 1957), 664-687. I shall be glad to supply the tables on request.

45 See J. P. Singh Uberoi, Politics of the Kula Ring: An Analysis of the Findings of Bronislaw Malinowski (Manchester: Manchester University Press, 1962); and Franz Michael, The Origins of Manchu Rule in China: Frontier and Bureaucracy as Interacting Forces in the Chinese Empire (Baltimore: Johns Hopkins Press, 1942), especially pp. 80-98.

${ }^{46}$ George M. Foster, "Peasant Society and the Image of Limited Good," American Anthropologist, 67 (April, 1965), 293-315; and James C. Scott, Political Ideology in Malaysia: Reality and Beliefs of an Elite (New Haven: Yale University Press, 1968), pp. 91-149. Foster, p. 296, associates the "image of limited good" with land shortage. But like clientage, it seems to be found also in peasant societies where land is not in short supply. 
else's gain to be one's own loss, would seem to encourage a strategy for self advancement that leads the individual to concentrate upon seeking concrete benefits for himself and his family, to reward others only on the basis of a quid pro quo, and to try to convert others into exploitable dependents.

It may be asked how it was possible for these four systems to operate with so little reliance on discrete structures. The answer would seem to lie in the fact that the particular needs of individuals can be met fairly effectively through dyadic interactions, and that discrete structures, general laws, and their impersonal enforcement are necessary only when categorical or collective goals are sought.

Barton's and Kiefer's descriptions of Kalinga and Tausug political life suggest that the traditional political process in these societies consists mainly of tasks that can be performed separately for various individuals, and in a decentralized fashion, i.e., of the ajudication of private disputes. Deliberate legislation does not occur in Kalinga where custom is the basis of law. In the Tausug state, law codes are formulated by the sultan, without the aid of a council or similar body. Administration, Kiefer reports, does not exist in the Tausug state as something separate from ajudication and the same may be said of Kalinga. ${ }^{47}$

The tasks of the Thai monarchy were more diverse and therefore required more complicated structures. To perform them, the monarchy established an elaborate system of administration. But that system lacked the structural stability and functional specificity found in the modern state. Tasks appear to have been assigned as much to individuals as to localities or departments. Governmental departments were subject to dissolution when their heads died or lost royal favor. Officialdom as a whole thus was unable to develop the cohesion and strength of a full-fledged Weberian bureaucracy. Finally, the Thai monarch, like other traditional Southeast Asian rulers, and unlike the monarchs of Europe, governed without a parliament. Legislation was the prerogative of the king, who usually ruled in a fairly arbitrary fashion. The Thai thus lacked the experience, so crucial to the evolution of the modern democratic rechtsstaat, of observing open debates on legislation by representatives of different social orders or points of view, taking the form of conflicting categorical demands that were resolved categorically. All this helps to explain why the king and the massive network of

${ }^{47}$ Kiefer, Tausug Armed Confict, p. 194. clients and subclients who staffed his government appear more prominent than the corporate structures of the premodern Thai state.

There remains the most nearly modern of the four Southeast Asian political systems, the Republic of the Philippines. Like other postcolonial states it has the usual functionally specialized branches of government patterned closely upon the model of its colonial tutor. And it has a growing number of formally organized voluntary associations including political parties which attempt to perform what Almond calls the articulation and aggregation of interests. Yet to a considerable degree, the interests of individuals in the Philippines are satisfied individually through direct dyadic arrangements of exchange between them and specific officeholders in the bureaucracy or the judiciary. Insofar as this occurs, the conversion of particular demands into categorical prescriptions becomes unnecessary, and the specialized associational and governmental conversion structures are bypassed.

\section{A Typology of Action Groups}

The main argument of this article has been that dyadic structures perform tasks differently than do groups of the type described by the "group theory" of politics. If the argument is valid, then it should be possible to devise a set of models to describe these and perhaps other structural types and their modes of performance.

I propose to do this at two different levels of what Giovanni Sartori has called the "ladder of abstraction." 48 I shall begin with a set of three very simple types, arrived at deductively, cast at a very high level of abstraction, and designed to be very broadly applicable. As suggested by Sartori the number of attributes of each highly abstract type will be kept to a minimum. Then, at a lower level of abstraction, which permits the filling in of more detail, I shall outline, with the help of a set of paired propositions, two contrasting types which, though they are in principle less broadly applicable, do fit, I believe, a large number of real institutions found in developing and more developed countries.

Each of the first three highly abstract types consists of three principles which, I suggest, are linked in each type. The principles are those of composition, action pattern and task. They are linked in that they are logically most

\footnotetext{
4s Giovanni Sartori, "Concept Misinformation in Comparative Politics," American Political Science Review, 64 (December, 1970), 1040-1046.
} 
suited to each other. By "most suited" I mean that the inner logic of each of the three is such that if one principle is chosen, the acceptance also of the other two provides logically the most efficient means (though not the only means) of goal achievement.

The three types are named "trait group," "web" and "collectivity." Each designates a distinctive type of action group. Their features are outlined in Table 1.

I shall not discuss the principles which comprise each type here. To elaborate on the characteristics of trait groups and webs would repeat arguments made elsewhere in this article. To discuss collectivities would greatly expand the article's scope. I have included the last type in the table simply in order to suggest how another basic type of action group might be described in terms of a few interrelated principles.

The structural elements of each type, that is to say composition and action pattern, have been listed first for the following reason: Structure can be a cause as well as a consequence of other elements of a system. Ancient institutions often display an ability to survive which may be hard to explain on functional grounds, and by their presence may discourage the growth of new institutions and the performance of new tasks. A similar conservative bias applies, I think, to structural principles. A society accustomed to certain of these is likely to make use of them even in those new institutions which it creates to replace old ones that have fallen into decline. If it is true, as I have argued here, that certain principles of composition, action and task are linked, then a society's addiction to given principles of structure will limit to some extent the types of goals it will be able to pursue. Conversely, if a society's leaders commit them- selves to pursuing wholly new types of goals, they must create not merely new institutions, but institutions based on the structural principles appropriate to these new types of goals.

The types suggest an approach to one of the problems of structural-functional analysis: The disjunction between those strategies for analysis that begin with structures and those that begin with functions. Perhaps it will be possible to move back and forth between structural and functional analyses more easily at the level of their underlying principles. A concern with such principles also may help one to connect micro-, macro- and middle-level analysis, a point previously made by René Lemarchand. ${ }^{49}$

It may be useful now to descend the ladder of abstraction a rung or two and to examine two further types which are sub-types of two of the types described in the previous table. Because the new types are less general than the previous ones, they can be outlined in greater detail. The trait group now takes the more specific form of a "trait association," with some degree of organization and a head. The web takes the form of a vertical web or "personal following." It need not be given a head for a web is inconceivable without a central figure. Both types, furthermore, are described as they operate in a setting where group attachment is voluntary and there is at least some competition among rival groups. Thus the types do not fit either a one-party state or a feudal fief.

In many but not in all of their characteristics these two types are polar ones, whose distinc-

${ }^{49}$ René Lemarchand, "Political Clientelism and Ethnicity in Tropical Africa: Competing Solidarities in Nation Building," American Political Science Review, 64 (March, 1972), p. 68.

Table 1. A Partial Typology of Action Groups

Three Types at High Levels of Abstraction

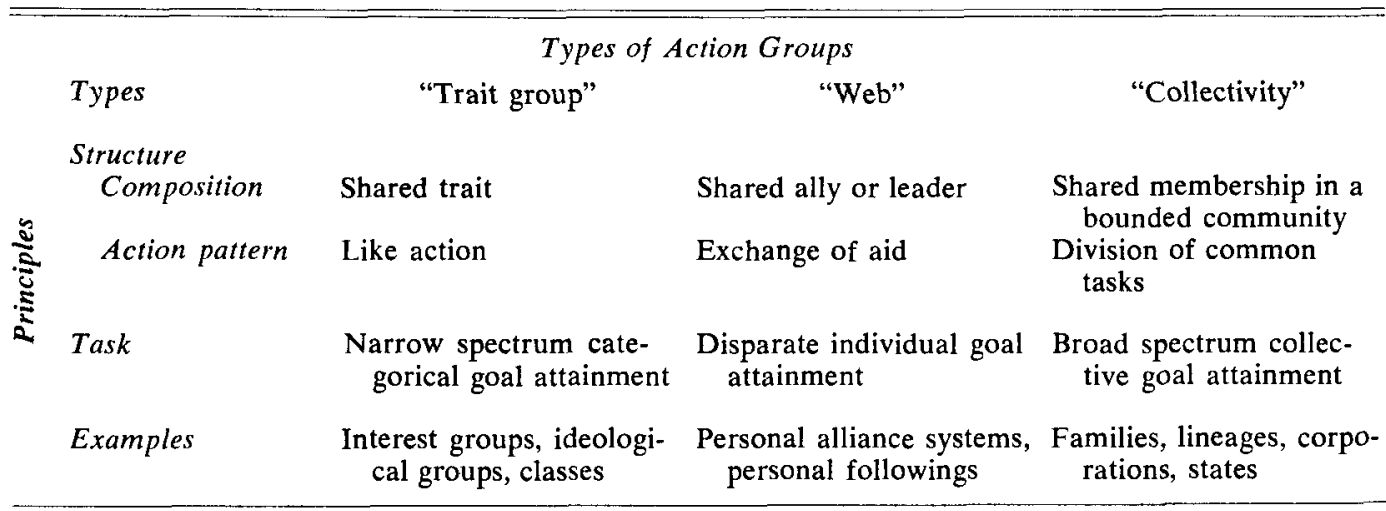


tive features can be placed at opposite ends of the same continua. For this reason, I shall describe the two types together, with the help of a set of paired propositions. These are the result of (a) deduction from simple structural concepts; (b) current theory concerning networks and dyads, especially that formulated by Robert Pehrson, George Foster, John Thibaut and Harold Kelley, Norman Whitten and Alvin Wolfe, and myself; and (c) a growing body of empirical research conducted in certain geographic regions where networks have attracted particular scholarly attention.

While the two types are meant to be quite broadly applicable, few institutions will conform to them exactly. Real institutions may combine different structural principles, or fall between the ends of a continuum. Or they may change their position on a continuum over time. Thus Adrian Mayer shows how the closest allies of the central member of an ego-centered web may over time form so tight a core that the central member becomes obscured by what has become a discrete multimember group. ${ }^{50}$ Finally, the peculiar traditions of a specific culture may in various ways alter a case which in other ways would fit the type.

${ }^{50}$ Adrian C. Mayer, "The Significance of QuasiGroups in the Study of Complex Societies," in The Social Anthropology of Complex Societies, ed. Michael Banton, ASA Monograph No. 4 (New York: Praeger, 1966), pp. 115-117.

\section{Table 2. Trait Associations and Personal Followings}

A Set of Paired Propositions

\section{DEFINITIONS}

A trait association is an organized group of persons united by the fact that they believe themselves to share a distinguishing trait, or fall into a distinguishing category. It has a head.
A personal following is a vertical dyadic web, bound together by the fact that the followers have a common leader.

\section{CONDITIONS}

The following propositions concerning the structure and performance of trait associations and personal followings assume a setting characterized by voluntary membership in, and a measure of competition between groups.

\section{PROPOSITIONS \\ Group Configuration}

Genesis

Trait associations:

Tend to grow out of pre-existing trait groups. (Recognition of the possession of a shared trait tends to precede organization and the selection of a head.)

\section{Reason for Appearance}

Tend to appear when there are objects of common interest which can be attained through collective

Are especially likely to appear when such objects cannot be attained through individual action. action.

\section{Personal followings:}

Tend to be the creations of their leaders. (A wouldbe leader by winning the adherence of various individuals, creates a following. Only then does a sense of community appear.)

Tend to appear when there are opportunities for mutually advantageous exchanges between leaders and followers.

Are especially likely to appear when leaders and followers can provide large gains to each other at small costs to themselves.

\section{Methods of Maintenance}

Tend to be maintained by emphasizing shared needs and shared dangers, and by the demonstration of gains resulting from past collective action.

Tend to be maintained by periodic exchanges of favors between leaders and followers. (Such favors may be either substantial or symbolic. Thus they may be the ends or the means of group cohesion.) Size

Size tends to be closely related to:

Size tends to be limited by:

The number of persons who share the trait.
The number of followers with whom the leader can maintain face-to-face relationships. 
The presence of parallel groups with similar traits and interests with which fusion can take place.

The presence of rival groups with conflicting traits and interests which can serve as stimuli for counter-organization.

Tend to be stable and enduring.

\section{Stability and Endurance}

For the group to endure, gains for participants need not equal or exceed costs in the short run, but must promise to do so in the long run.

Endurance is threatened by indications that individual or group goals cannot be attained through collective action. solution if:
The resources for distribution available to the leader.

Tend to be unstable and of short endurance.

For the group to endure, gains for participants must equal or exceed costs in the short run.

Personal followings are highly vulnerable to fragmentation, shrinkage, disintegration, or dis-

The leader loses his access to distributable resources.

The leader is challenged by rival leaders with greater resources.

The leader dies without being replaced at once by a suitable successor with equal resources.

\section{Roles of Superordination and Subordination}

\section{Group Headship}

Heads tend to be "officers," entrusted with authority to act by their groups.

Their official acts tend to be enforced by sanctions imposed by the group.

Such sanctions tend to be most effective when groups are multi-functional or mutually exclusive, or both.
Heads tend to be "leaders" who act on their own initiative.

Group sanctions to compel obedience to leaders tend to be rare.

Individual compliance with the leaders' commands tends to depend heavily upon the consent of each follower.

\section{Group Membership}

The rank and file tend to regard themselves as "members" having rights and obligations towards the group.
The rank and file tend to regard themselves as "followers," having claims upon and owing favors to their leader.

\section{Criteria for Headship}

The primary criterion for officership tends to be that the officer share the traits which distinguish the group.
The primary criterion for leadership tends to be that the leader have status or resources superior to those of his individual followers.

\section{Responsibility or Responsiveness}

Officers tend to a high degree to be responsible to their groups for actions taken in the group's behalf.

Responsibility tends to be enforced by collective action involving the whole group or representatives of the group.

Responsibility tends to be highest on matters of general group policy.

Officers tend to be relatively unresponsive to the private demands of individual members.
Leaders tend to a high degree to be responsive to the private demands of individual members.

Responsiveness tends to be enforced through pressure from individual followers, rather than by collective action involving the whole group.

Leaders tend to have considerable freedom to set broad goals and policies, as long as they satisfy the immediate private needs of their followers. 


\section{Prestige}

Within the association, the prestige of the officer and of members tends to a high degree to depend on their services to the association.

In the larger community, the prestige of the officer and of members tends to a high degree to depend upon the prestige of the trait group as a whole.
Within the following and the larger community, the prestige of the leader tends to a high degree to depend on the size of his following.

Within the following and the larger community, the prestige of an individual follower tends to a high degree to depend on the prestige of the leader, and the follower's closeness to him.

(The distribution of prestige in the community resembles the top of a circus tent: The peaks, supported by the points where poles are placed, denote leaders whose prestige is their own. The sloping areas near the peaks represent the derivative prestige of close followers who are raised above the common mass by their leaders. The troughs denote the prestige of minor followers and the unattached.)

\section{Goals and Goal Attainment \\ Types of Goals}

Tend to focus upon a narrow spectrum of related Tend to focus upon a broad spectrum of particular categorical or ideological goals.

\section{Agreement on Goals}

Tend to require a high degree of agreement con- Tend not to require a high degree of agreement cerning specific goals. concerning specific goals.

\section{Alteration of Goals}

Tend to find it difficult to alter specific goals.

Tend to find it easy to alter specific goals.

Participation in Rewards and Costs

Rewards tend to be of a kind that benefit all who share a trait, whether or not they are members of the trait association.

Hence trait-wide participation in the association, or trait-wide contribution to its costs, will be sought.

\section{Methods of Goal Attainment}

Tend to rely to a high degree upon collective action by the membership.

Frontal attacks against opposing groups are a favored tactic.
Rewards tend to be of a kind that can be restricted to members of the following:

Within the following, shares in the rewards tend to be closely related to the follower's value to the leader.

Tend to rely to a high degree upon the manipulative skill of the leader.

Among favored tactics are the following: Playing other actors off against each other; wooing away the allies of others; monopolizing access to distributors of resources.

\section{Communication}

Officers tend to communicate with members in Leaders tend to communicate privately with each broadcast fashion.

follower.

Messages tend to be categorical in content.

Messages tend to be particular in content.

A high value tends to be placed on confidential information, diverse sources of information, and direct access to originators of information. 
Goals and Rewards of Headship

To a relatively high degree officers are obliged to To a relatively high degree, leaders are free to focus their efforts upon the attainment of group focus their efforts upon the attainment of their prigoals. vate goals.

The rewards received by officers tend to be relatively modest, and be set by the group.
The rewards received by leaders tend to be relatively large, and to be set by themselves.

\section{The Interaction of Groups in the Polity}

\section{Similarities and Differences Between Groups}

Rival associations tend to be dissimilar in their Rival followings tend to be similar in their comcomposition and goals. position and goals.

Inter-association disputes tend to turn on categorical issues.
Inter-following disputes tend to turn on "personalities" and spoils.

\section{Expansion and Consolidation of Groups}

Associations tend to be expanded through the broadening of categories, and the "nesting" of narrower trait associations within more comprehensive ones.

This is made possible by broadening the spectrum of goals.

Followings tend to be expanded through the "pyramiding" of leaders. Under this procedure several lesser leaders, each accompanied by those who remain his personal followers, become the followers of a higher leader.

This is made possible by supplying larger quantities of the same types of rewards.

Consolidation through pyramiding tends to be limited by the resources available to the highest leader.

\section{Changes in Individual Loyalties}

Relatively few members shift their allegiance from one association to another.

The shifting of individual allegiance from one leader to another tends to be fairly common.

Changes in allegiance tend to be affected by the ability of rival leaders to provide individual rewards to their followers.

The Stability of Inter-Group Alliances

Alliances between associations tend to be relatively stable.

Two-directional reversals of alliances are very uncommon (i.e., $A B$ vs $C D$ may become $A B C$ vs $\mathrm{D}$ or $\mathrm{A}$ vs $\mathrm{BCD}$, but not $\mathrm{AC}$ vs $\mathrm{BD}$ ).
Alliances between followings tend to be relatively unstable.

Two-directional reversals of alliances are not uncommon.

\section{Omnibus Propositions}

\section{The Resolution of Conflict}

Systems composed of trait associations tend to resolve conflicts by the following means:

Fostering an awareness among individuals and groups that they have in common higher interests which override their areas of disagreement.

Under certain conditions: By creating stable majorities which are able to impose solutions to conflicts.
Systems composed of personal followings tend to resolve conflicts by the following means:

Avoiding issues that are socially divisive.

Employing bargaining as a method of conflictresolution.

Making rival groups open in their recruitment, heterogeneous in composition, syncretic in policy, and flexible in their alliances.

Providing opportunities for individual (as distinguished from group) social mobility, and thereby placating potential advocates of conflict. 


\section{Organization for Goal Achievement}

Systems composed of trait associations tend to be better suited than systems composed of personal followings for the concentration of collective effort towards the achievement of clearly defined collective goals. Specifically, they are well suited for the following tasks:

Fusing scattered private goals into collective goals, devising long-range programs for their attainment, and mobilizing for such programs support which is massive, disciplined, and sustained.

Forcing clear-cut choices between incompatible goals.

Restraining individual and sub-group rivalries that jeopardize collective goals.

Creating officers who are committed to collective goals, maintaining group control over them, and enforcing compliance with their commands.
Systems composed of personal followings tend to be better suited than systems composed of trait associations for the rapid attainment of the particular goals of individuals. Specifically, they are well suited for the following tasks:

Focusing attention upon goals which are concrete and quickly attainable.

Fostering mutual aid between dissimilar individuals in the pursuit of their private goals.

Creating leaders who are sensitive to the needs of individual followers, and able to intercede with power holders on their behalf.

\section{Effects upon National Cohesion}

Nations whose rival political groups are trait associations tend to avoid localistic politics.

Nations whose rival political groups are trait associations tend to be divided on lines of ideology or general policy.

Nations whose rival political groups are trait associations tend to achieve community-wide or nation-wide unity by broadening categories.

\section{The Future of Dyadic Structure}

Dyadic arrangements for the advancement of self-interest seem natural to man. They satisfy the yearning for security, favored treatment, and power. They provide a simple means for the advancement of self-interest which require a minimum of elaborate organization, trust in a minimum number of people, and minimal delay in the achievement of private goals. Dyadic arrangements furthermore are extremely flexible and can be employed in diverse situations to mobilize a wide variety of individuals. But they have disadvantages as well: Stable dyads restrict their members' freedom to engage in more profitable exchanges. Vertical dyads can be demeaning for the subordinate partners, leave them in disadvantageous bargaining positions, and may deprive them of the advantages to be gained from class based organization. All concerned in a dyadic system may see as unjust the favoritism that usually characterizes dyadic interaction. Under certain conditions, the disadvantages of dyadic political arrangements may seem to outweigh their benefits and lead to
Nations whose rival political groups are personal followings tend to have localistic politics.

Nations whose rival political groups are personal followings tend to be divided by a simple struggle for power.

Nations whose rival political groups are personal followings tend to achieve community-wide or nation-wide unity by replacing particular goals with categorical or collective goals.

their abandonment. What are these conditions and why do they seem to be most common in modern societies? James Scott has explored this subject at length in two excellent papers. ${ }^{51}$ I should like to add a few comments.

The conditions are not necessarily the same for the ruler and the ruled. From the point of view of the ruler the staffing of government with personal clients rather than with those who have most skill becomes unnecessary when he can count on the loyalty of all his subordinates as a matter of course. This is most likely to be the case when officials lack the ability to overthrow the ruler or influence the succession. Such was the case in the stable constitutional monarchies of nineteenth century Europe and is the case in modern democracies. It is not the case in many developing countries, particularly in embattled traditional monarchies where the ruler feels threatened by many of his own ser-

${ }^{51}$ James C. Scott, "The Weakening of Rural PatronClient Ties in Colonial Southeast Asia," and "How Traditional Rural Patrons Lose Legitimacy," unpublished papers, 1971. 
vants, or in such "bureaucratic polities" as contemporary Thailand, where the outcome of the struggle for control of the government is determined by the maneuvering of bureaucratic cliques and not by the results of popular elections.

From the point of view of the ruler also, the attachment of the common people to his officials or to a landholding nobility becomes unnecessary and need not be allowed when the ruler finds it possible to control his subjects and to extract taxes or services from them by other means. His ability to do the latter is likely to increase as population grows and labor shortage is replaced by land shortage. For then subjects are not likely to run away and corvée labor can be replaced by landless laborers and soldiers hired with taxes taken from the agricultural sector.

From the point of view of the common man, the protection of a patron ceases to be advantageous when he can expect to be secure in his life and property and count on equal treatment before the courts without the help of a powerful protector. This condition is likely to be achieved in a rechtsstaat, a state governed by the impersonal rule of law. Lacking this, it is likely to be achieved also where the individual has available to him membership in a discrete group which can offer him such protection.

Finally, from the point of view of both potential patrons and clients, these roles become unattractive when it begins to be in their interest to have freedom to shift their superordinates, subordinates, or trading partners at will. This, of course, is the case in a modern market economy. Where such an economy prevails, one can expect dyadic structures to deteriorate in the political sphere as well.

An apolitical bureaucracy, an easily taxable populace, a rechtsstaat, freedom of associational activity, and a market economy-these conditions are all characteristic of the modern democratic state. It is not surprising therefore that a political science which has devoted most of its attention to the study of modern Western democracies should have found little reason to interest itself in dyadic structures. As other societies achieve similar conditions, we may expect this to be the case there as well.

Still, in modern states where some of these conditions are absent, dyadic and other "traditional"structures may continue to be important. Thus, in the Soviet Union and China, the proscription against the creation of formally organized teams of would-be competitors for those in power, either outside or within the ruling party, has resulted in the emergence instead of informal cliques and personal followings reminiscent of those found in premodern polities. ${ }^{52}$

And even in modern democracies at certain levels of the political system dyadic structures flourish. Thus, while the mass of American citizens are accustomed to confining their political activity to membership in various voluntary associations and to the periodic casting of ballots, those who aspire to positions of high leadership in these associations organize themselves dyadically. The reason is simple: The benefits derived from general legislation can be shared by innumerable people. But high offices are in limited supply. If one hopes to be a presidential advisor, one had best attach oneself to a promising candidate early in the game.

To conclude: While traditional patron-client relationships appear to be breaking down in many peasant societies, other types of dyadic structures and techniques will continue to play a part in politics as long as political actors seek and are able to advance their interests particularistically. The study of the political process is deficient insofar as it fails to give attention to such structures.

${ }^{52}$ Andrew J. Nathan, "A Factionalism Model for Chinese Politics," The China Quarterly, 53 (January/ March, 1973). 